\title{
EDITORIAL
}

\section{One Health Approach to Disease Prediction and Control}

\author{
Abraham Haileamlak, MD, Professor of Pediatrics and Child Health
}

DOI: http://dx.doi.org/10.4314/ejhs.v26i4.1

Though the concept of One Health appears new for many practitioners, it extends back to ancient times. The recognition that environmental factors can impact human health can be traced as far back as to the Greek physician Hippocrates when he promoted the concept that public health dependent on a clean environment (1).

In modern medicine, European physicians practicing in the $17^{\text {th }}$ and $18^{\text {th }}$ centuries were advocating for the idea that human, animal and environmental health are linked as they believed that there is no dividing line between animal and human medicine $(2,3)$. Thereafter, many more practitioners advocated and demonstrated the interaction between human and animal health and environment.

As shown above, though the concept of human and animal health interaction has long been recognized globally, human and animal medicine were practiced separately until the 20th century. In recent years, through the support of key individuals and vital events, the One Health concept has gained more recognition in the public health and animal health communities. However, term "One Health" was first used in 2003 when a journalist was quoting an expert saying, "Human or livestock or wildlife health can't be discussed in isolation anymore- there is just one health" (4).

Evidences showed that the ongoing population growth, climate change and environmental contamination threaten both human and animal populations and caused increased transmission of diseases from animal to human. The One Health approach is therefore underlines the significance of transdisciplinary and transboundary efforts which has been recognized as a major element of disease control and prevention strategies by international agencies (5-8). The concept of health could be defined on at least three different levels: the individual level, the group or population level, or the ecosystem level.

Reginal One Health initiatives are now being implemented as network in hot-spot regions for vector-borne diseases. Such initiatives are One Health Central and East Africa (OHCEA) in Africa, South East Asia One Health Universities Network (SEAOHUN) in Asia One Health Sweden in Europe and the Americas.
The current issue (Vol. 26, No 4), the fourth issue of the year contains one editorial focusing One Health Concept, ten original articles on varied subjects and three case reports focusing on different topics.

I invite readers to read through these articles and appreciate or utilize the contents. I also encourage readers to forward comments and suggestions.

\section{REFERENCES}

1. The Internet Classics Archive. Hippocrates. "On Airs, Waters, and Places". 400 BCE. Translated by Francis Adams. http://classics.mit.edu/Hippocrates/airwatpl.html. Accessed July 2016.

2. A. F. LaBerge. "Mission and Method. The Early Nineteenth-Century French Public Health Movement." Cambridge, England: Cambridge University Press, 1992.

3. Kahn LH, Kaplan B, Steele JH. "Confronting zoonoses through closer collaboration between medicine and veterinary medicine (as 'one medicine'). Veterinaria Italiana 2007; 43(1): 519.

http://www.onehealthinitiative.com/publications/0 $1 \% 20 \mathrm{Kahn} \% 20$ et\%20al\%20\%20519\%208Mar07.pdf. Accessed July 2016.

4. Weiss, R. Africa's Apes Are Imperiled, Researchers Warn. The Washington Post. Apr. 7, 2003.

5. Daszak P, Zambrana-Torrelio C, Bogich TL, Fernandez M, Epstein JH, Murray KA, et al. Interdisciplinary approaches to understanding disease emergence: the past, present, and future drivers of Nipah virus emergence. Proc Natl Acad Sci U S A. 2013;110(Suppl 1):3681.

6. Rabinowitz P, Scotch M, Conti L. Human and animal sentinels for shared health risks. Vet Ital. 2009;45:23-4.

7. Kahn LH. The need for One Health degree programs. Infection Ecology and Epidemiology. 2011;1:7919.

8. Karesh WB, Dobson A, Lloyd-Smith JO, Lubroth $\mathrm{J}$, Dixon MA, Bennett M, et al. Ecology of zoonoses: natural and unnatural histories. Lancet. 2012;380:1936. 